\title{
AMERICAN AND EUROPEAN MODELS OF HUMAN RESOURCES MANAGEMENT Which one is more suitable for the Turkish case?*
}

\author{
Armağan Emre ÇAKIR**
}

\begin{abstract}
Corollary to the fact that Human Resources Management first flourished in the American management literature, initial HRM models bore the affects of the managerial milieu in the USA. With the spread of the HRM concept, however, to other developed countries, alternative models started to thrive some of which had the claim of universality. A group of models fashioned for Europe was the most promising alternative to the American models. This article outlines the American and European models of HRM, questions the pertinence of each for the Turkish case, and suggests some alterations if they are to be applied to the HRM practices in Turkey.
\end{abstract}

\section{Introduction}

At its inception, Human Resources Management (HRM) was thought to have absolute universal applicability with a static model. Probably the hype at the beginning prevented the students of HRM from realising its relativity. Preliminary attempts to transplant/export the HRM mechanisms as a whole to other countries or regions proved problematic, and the American models needed to be revised before being put into practice in other places. The standpoint of relativity of HRM models gained prominence an extreme instance of which is represented by Pieper ${ }^{1}$ who advocated the idea of unfeasibility of conceiving a universal HRM model in general or a European model in particular. Yet, for the aims of this article, we will not go that far, and depart from the premise of possibility of discerning a common European

* This article is a reconsideration of some propositions in Çakır, A. E. (1999), Human Resources Management In International Context:'With Special Reference to the UK, Spain and Turkey, Istanbul: Marmara University, European Community Institute, unpublished PhD thesis.

** Dr., Marmara University European Community Institute [e-mail:acakir@marmara.edu.tr] 
pattern. Let us examine the American and European models in turn, and then discuss the suitability of each for the HRM practices in Turkey.

\section{American Models of HRM}

In the literature, exhibits or classifications of models of the American HRM are mostly either a mixture of American and British models ${ }^{2}$ or not exhaustive $^{3}$. A more suitable classification is supplied by Sparrow and Hiltrop. They categorise the models under three titles: Michigan, New York and Harvard models. The Michigan and New York models together are called 'matching models of HRM'.

\subsection{Matching Models \\ 1.1.1 Michigan Model}

This model, as one of the first in the literature, belongs to Tichy, Fombrun and Devanna 5 . In the concept of 'Human Resources Management', the authors emphasise the term 'resource'. Like other resources of the firm, they assert, people have to be managed in such a way that they are "obtained cheaply, used sparingly and developed and exploited as fully as possible6". Management of human resources (HR) should be in accordance with broad organisational requirements like quality or efficiency. There has to be a fit between HR and business strategies (though not manifest in the model). They define five areas of HRM which have to be both coherent and consistent among themselves and also linked to the business strategy:

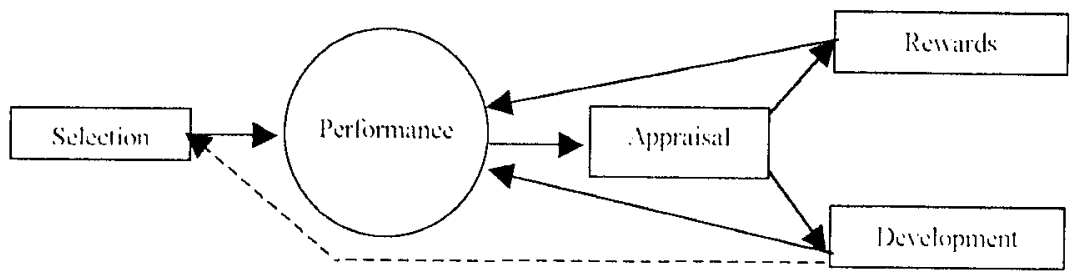

Figure 1: The Michigan Matching Model of HRM

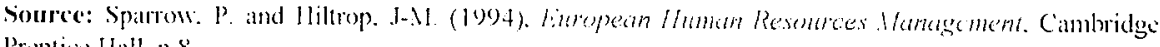
Prentice Itall. p.8.

\subsubsection{New York Model}

The New York model was presented to the literature by Schuler and Jackson $^{7}$. In the centre of the model are the three generic competitive strategies devised by Porter $^{8}$. Porter claims that to achieve competitive 
advantage, a firm should follow either 'quality enhancement', or 'innovation' or 'cost leadership' strategy. Each option requires different behaviours of the firm in different areas of HRM namely, 'planning, 'staffing', 'appraising', 'compensating' and 'training and development'. These five areas have different dichotomous choices under them (called 'HRM practice menus'). In accordance with its preference from the three generic competitive strategies, the firm should pick up one from each dichotomous choice:

\section{Table 1: HRM Practice Menus}

\begin{tabular}{|c|}
\hline 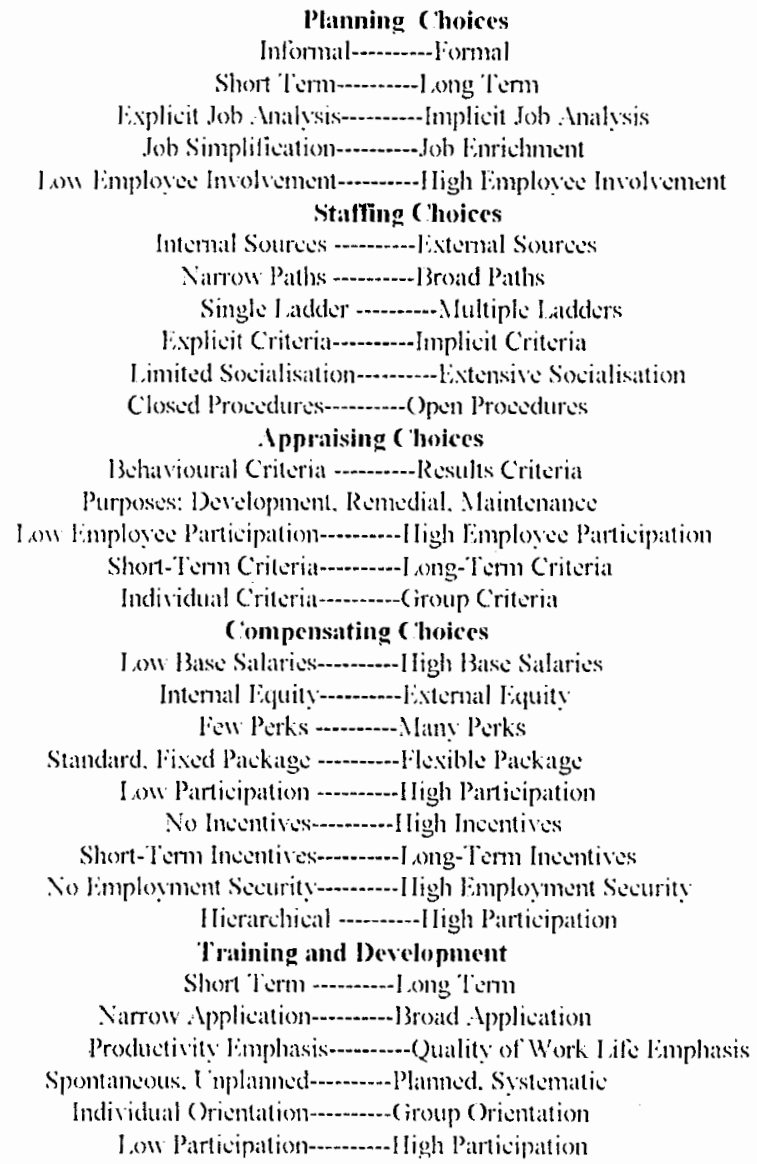 \\
\hline
\end{tabular}

Source: Schuler. R. S and lackson. S. L. (1987) "J inking competitive slrategies with human resoures

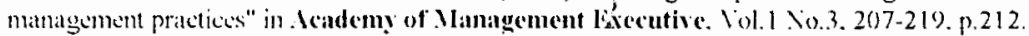

Each strategy has its role behaviours expected from the employees: 


\section{Table 2: Employee Role Behaviours for Competitive Strategies}

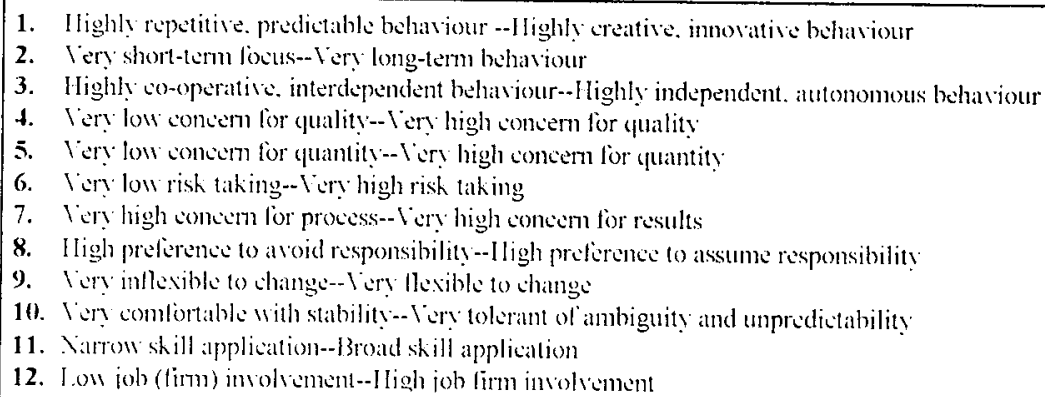

Source: Schuler and Iachson, S. F. (1987), p. 202.

\subsection{Harvard Model}

Harvard model was developed by Beer et. $a^{9}$ at Harvard Business School. Their model -or 'the map of the HRM territory' as they prefer to call it- has five components: 'stakeholder interests', 'situational factors', 'HRM policy choices' 'HRM outcomes', and 'long-term consequences':

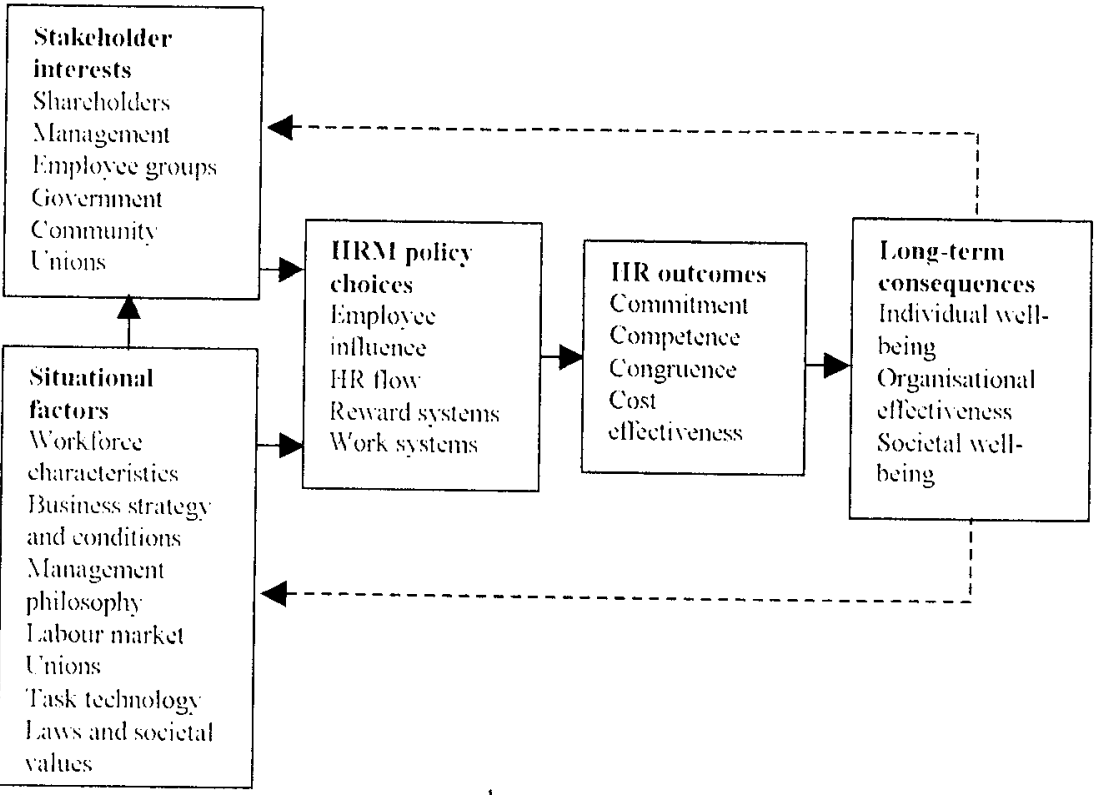

Figure 2: The Mip of the HRM Territor

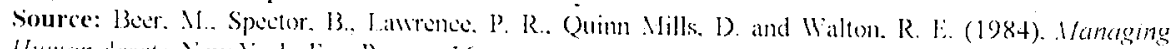
Hownan ilssets. New York: Irese Press. p. 16. 
The interesting feature about the model is that although it accepts that the management has the upperhand, it also postulates that the voice of other stakeholders like shareholders or employee groups have a say -or at least an influence- in the formation of HR policies. With this feature, the model leaves way for 'co-determination', and as such constituted a point of departure for some European models ${ }^{10}$.

\subsection{Common Points of the American Models}

An overview of American HRM with main common characteristics underlined is given by Claydon ${ }^{11}$ together with references to the representative authors of each characteristic:

- An emphasis on the importance of strategy in the management of organisations and the desirability of linking strategies for the management of organisational resources ${ }^{12}$,

- An insistence that basic conflicts of interest are not an inevitable feature of employment relationship, and that effective management can 'integrate the goals of employees with those of the firm ${ }^{13 '}$. In this, HRM has not incorporated the explicitly pluralist focus on management's role in 'balancing and rebalancing the multiple interests served by the company ${ }^{14}$ ' which has a feature of some of the writing of the Harvard school,

- A focus on developing individual workers' commitment to the organisation, i.e. loyalty and willingness to remain with the organisation, and strong motivation to deliver high levels of performance ${ }^{15}$,

- The importance of developing a strong organisational culture which is supportive of HRM policies aimed at developing employee commitment. The values of the founders of companies have been seen as one of the most important factors in developing such cultures ${ }^{16}$,

Sparrow and Hilltrop provide another design to shed a light to the two main groups apparent in the American HRM literature: 


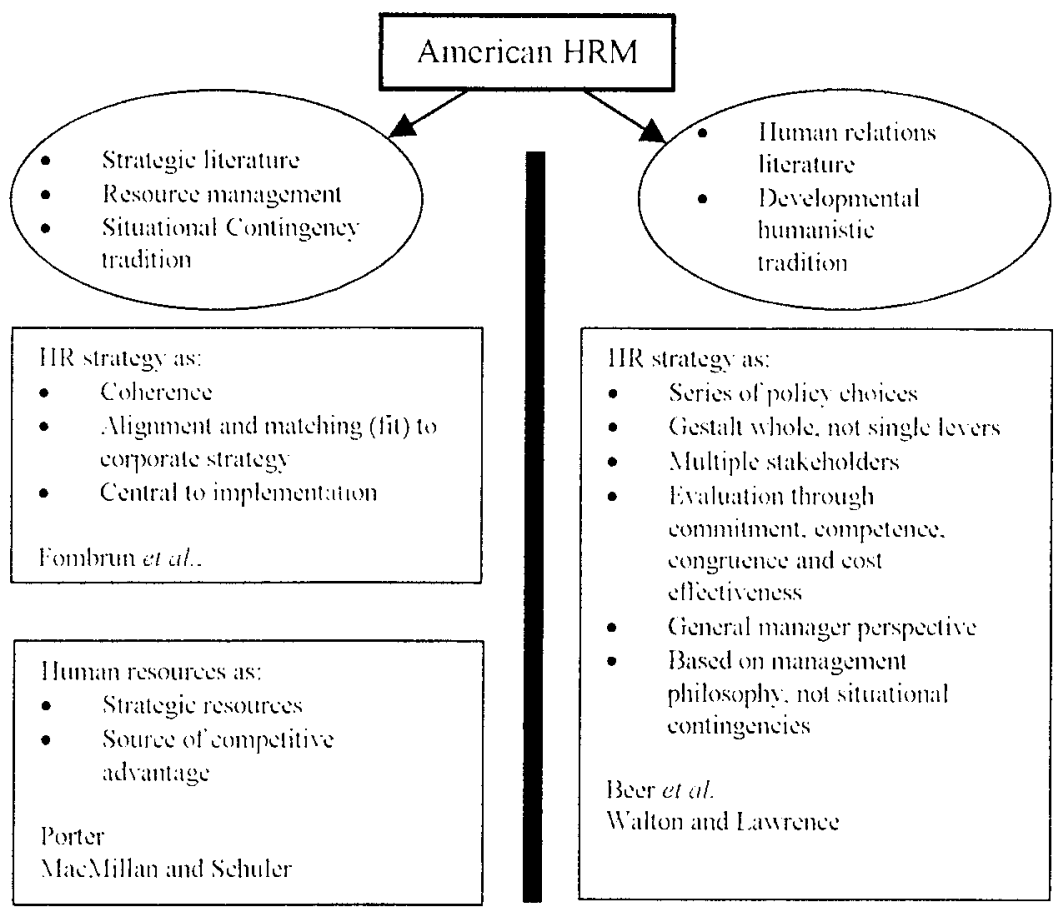

Figure 3: A Schism in American Thinking aboul American HRM Source: Sparrow and Hilltrop. (1994). p.?

\section{European Models of HRM}

Bournois and Brewster put forward three arguments to justify international comparisons of concepts and practices of HRM from a European perspective: i) due to the inevitable effects of internationalisation and globalisation trends, managers are no longer only exposed to technical and economic changes but also to cultural differences ${ }^{17}$; ii) in the last decade some practices like Japanese management or strategic management have become fashionable. A comparative approach may exhibit the applicability and relevance of these practices in other national contexts; iii) international comparisons often draw on three main units: USA, Japan and Europe.

One of the prominent authors of the field of comparative industrial relations, Bean holds the view that whereas HRM is accompanied by a marginalisation of the unions, or the creation of union free enterprises, in 
European countries it has operated in the presence of the unions sometimes involving them in the operation. Another difference between the US and Europe, according to Bean, is that managements in Europe have less autonomy -because of, for example legal constraints on employment contract and establishment of pay levels. He says that "the evidence suggests that the US-based concept may not fit comfortably with the reality of human resource management in Europe.... ${ }^{18 "}$

Such general remarks about singular European countries may be valid. However, the idea that Europe is a homogenous entity is questionable ${ }^{19}$. Holden underlines the pitfalls in establishing a single model that would explain the HRM matters at the European scale:

In the European Community ... there are significant differences in human resource practices. For example, in many Italian organisations recruitment is often based on the contacts of family and friends, whilst although such practices do exist in Northern Europe, they are generally frowned on as a form of nepotism.

In France the use of graphology is widely used in the selection process but hardly used in Scandinavia or the UK where there is more scepticism about its effectiveness. In Germany and Sweden there are large numbers of directors and senior executives who have engineering qualifications whereas in the UK they are more likely to have accountancy backgrounds. In addition labour market policies differ widely across Europe and there can be significant variance in policies and practices between countries which appear similar in their socio-economic and political structures, for example between Denmark and Sweden 20 .

A similar quote belongs to Bournois and Chauchat:

We now have a better idea of what is meant by the European dimension, but there is still a great deal of controversy as to what makes a manager. What are the similarities between the concepts of 'cadre', 'manager', 'führungskraft', 'quadro', 'Kader', 'dirigenti', 'quadri'...21 ?

This cynical view about devising a European model of HRM has gone so far that among others Pieper established his work on the idea of impossibility of rendering this task at international scale in general and at European scale in particular; according to him, "first of all, Human Resources Management seems to be more a theoretical construct than an applied 
reality22". Because, what companies generally practise is personnel management instead of HRM; they ignore cultural or general environmental differences in pursuing their international HR policies. Secondly, practical and theoretical concepts in the various nations vary widely. Thirdly, culture has been exaggerated in its influence on HRM practices.

Nevertheless, there are some others who maintain a contrary view. Shenton ${ }^{23}$ claims that it is possible to delineate a 'European' management in general on the following two tracks: first, the definition and description of features that distinguish management in Europe as opposed to management elsewhere (for example, the US), and secondly, the sum or synthesis of the mosaic of national styles (for example, French management or German management) in which different national styles are examined critically.

Keeping the above points in mind, we may now analyse the models of comparative HRM at European scale:

\subsection{Harvard Model Revisited}

Beer et al. in devising their model already acknowledged the importance of the comparative approach like Bournois and Brewster mentioned above:

... (V)ariations in Human Resources Management policies and practices across countries offer useful alternatives for US managers to learn from. This comparative perspective allows managers to examine and question the ideology and assumptions that underlie their own Human Resources Management practices. Looking at what managers in other countries do can also suggest alternative models for integrating people and organisations ${ }^{24}$.

Six years after the publishing of their book, Poole took up the model to derive an international model from it by making a combination with his own work on comparative industrial relations ${ }^{25}$. For him, the Harvard model is pluralist in nature in the sense that it accepts differing approaches and attitudes towards the employment relationship, but "some of its features reflect its North American origin" and three substantial alterations are necessary on it ${ }^{26}$ :

- The global development of business,

- The power of different stakeholders, 
- The more specific links between corporate and HR strategies.

Though his focus is on examining industrial democracy, he underlines the notion of strategic choice in international HRM. As such, Poole's model takes the following form:

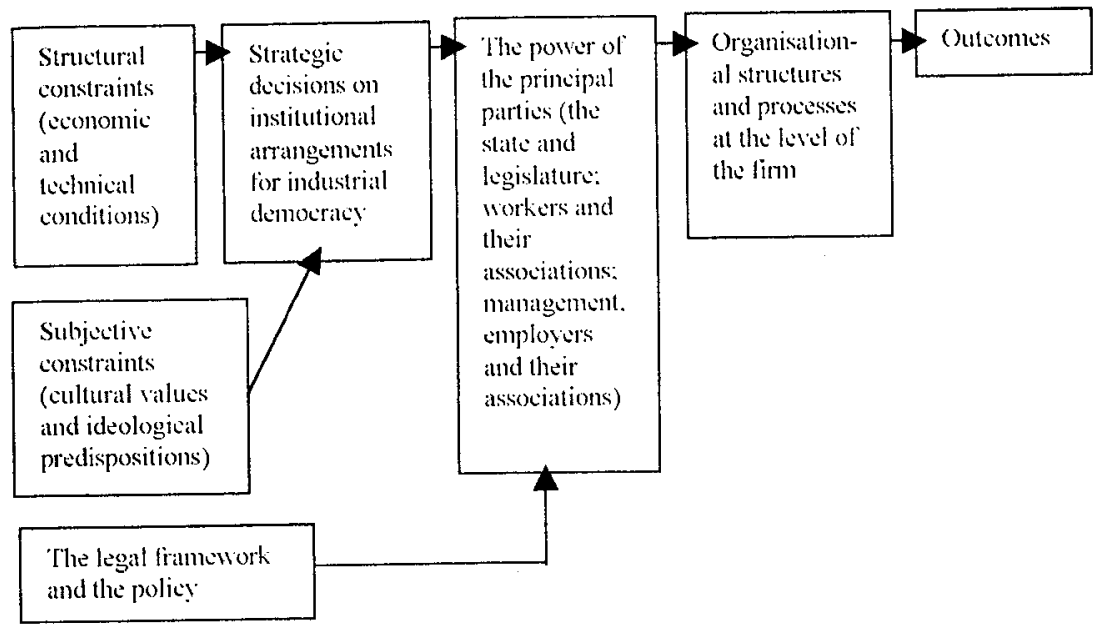

Figure 4: Poole's Model for the Comparative Analysis of Industrial Democracy Source: Pools. M. (19\%) "Jiditorial: Human Resource Management in an international perspective" in International Joumal of Thman Resource Lanagement. 1(1). Juns. 1-15. p. 6.

The main areas of the strategic choice are employee influence, HR flow, reward systems, and work systems. Let us examine these areas shortly:

Employee influence: Empowerment of the workforce takes different forms in different national and organisational cultures (quality circles, job enrichment, union representation, works councils, co-determination, producer co-operatives, self-management etc.). However not all of these forms fit HRM frameworks, but "most are (a) relevant, and (b) are the subject of vibrant comparative research"27.

HR flow: It has three components: 'inflow' (recruitment, assessment and selection, orientation and socialisation), 'internal flow' (evaluation of performance and potential, internal placement, promotion and demotion, education and training) and 'outflow' (termination outplacement and retirement). These are related with the government legislation, educational institutions, unions, societal values and public policy of each national and regional context. 
Reward systems: Traditional methods like pay, as well as intrinsic rewards such as employee satisfaction and motivation to work...

Work systems: Behind this, is the presupposition that gaining high commitment from employees takes an important part in the agenda of all the organisations, and the various ways of achieving this reflect work-related value systems. These systems in turn need to be recognised and integrated.

Besides these four areas he adds to the Harvard model, Poole also lays emphasis on the concepts of 'globalisation', 'power' and 'strategy' in the evolution of international HRM. Multinational companies, and the relations with such bodies like the EC are new themes too. These factors together with new technologies, the economies of large markets, and market competition are the factors to be taken into consideration in the creation of HRM strategies.

\subsection{The Brewster-Bournois, Brewster-Hegewisch, and Brewster Models}

The amendments Poole made on the Harvard model are not enough for Brewster and Bournois ${ }^{28}$; by referring to Guest's phrase from $1990^{29}$ they state that this conception of HRM is a reflection of the 'American Dream'. What Brewster and Bournois develop is an international model -or what they unassumingly call 'perspective'- based on the Price Waterhouse Cranfield Survey. Since that survey was based on European data, it is their claim that, their international model is from a European viewpoint, and as such tentative. To support their arguments they quote, among others, Thurley and Wirdenius who argued that a unique European management approach is

emerging and cannot be said to exist except in limited circumstances; broadly linked to the idea of European integration, which is continuously expanding further into different countries (i.e. the twelve);

a reflector of key values such as pluralism, tolerance, etc., but is not consciously developed from these values;

associated with a balanced stakeholder philosophy and the concept of Social Partners. 30 


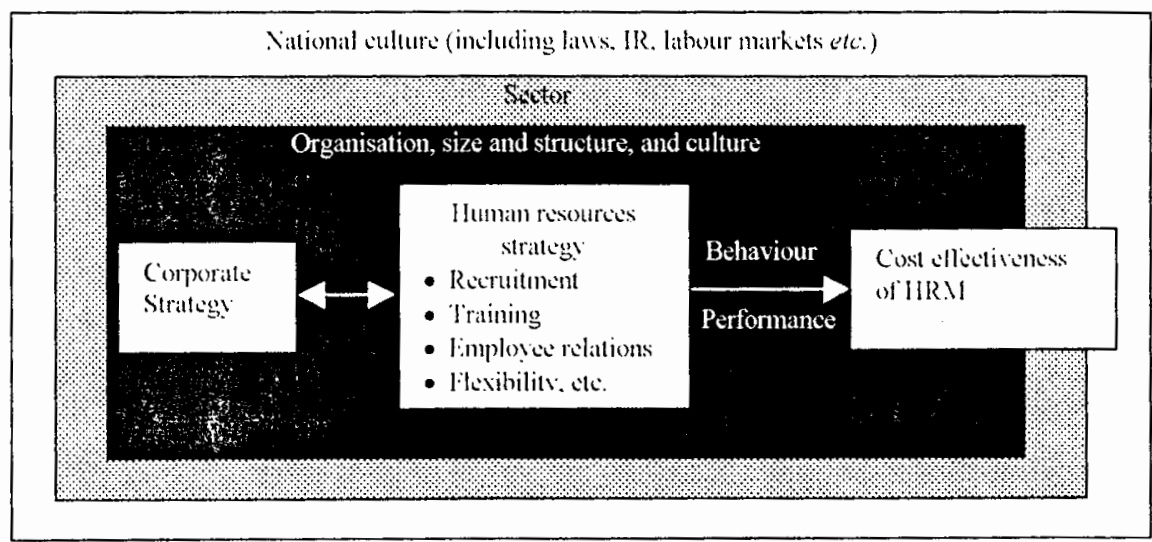

Figure 5: The Brewster and Bournois Model for livestigating HR strategics

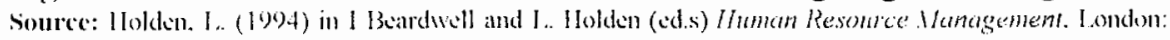
P'itman P'ublishing. $625-654$, p. 612

The Brewster and Bournois model was later revised and renamed in the following form by Brewster and Hegewisch in 199431:

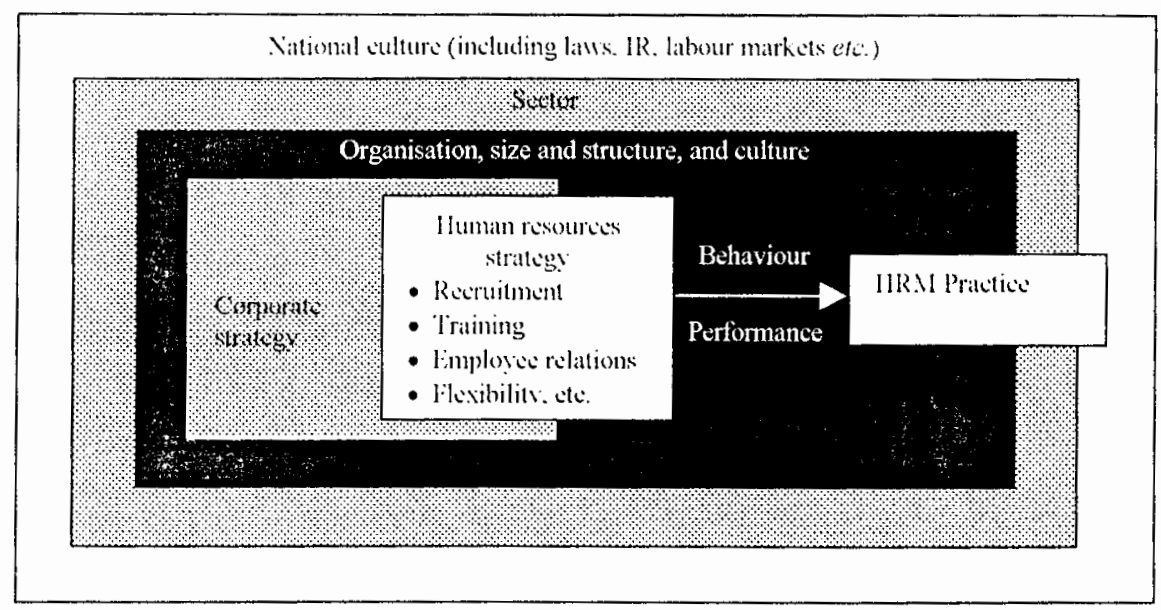

Figure 6: A Model for Investigating HR Straltegics: The Europcan Environment Soure: Brewster. Cand llegewisch. 1. (1994) "JIR.M in Furope: lswes and opportunities" in C'

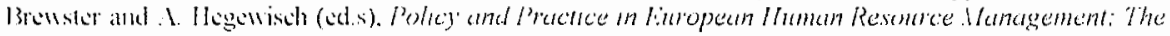

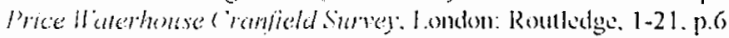

What Brewster and Hegewisch highlight in this model is that first, HR strategies are "placed firmly within, though not entirely absorbed by, the business strategy....; there is an interaction between the two rather than one following from the other". Secondly, "the business strategy, HR strategy and 
HR practice are located within an external environment of national culture, power systems, legislation, education, employee representation etc.)". For them, "despite the clear national and regional distinctions, there is an identifiable difference between the way in which HRM is conducted in Europe and the situation in the USA". They underline "the influence of such factors as culture, ownership structures, the role of the state and trade union organisation". For example, they maintain, "the European evidence suggests that managements can see the unions.... as social partners with a positive role to play in Human Resources Management". ${ }^{32}$

Later on, a third model was derived -this time only- by Brewster:

\section{Environment}

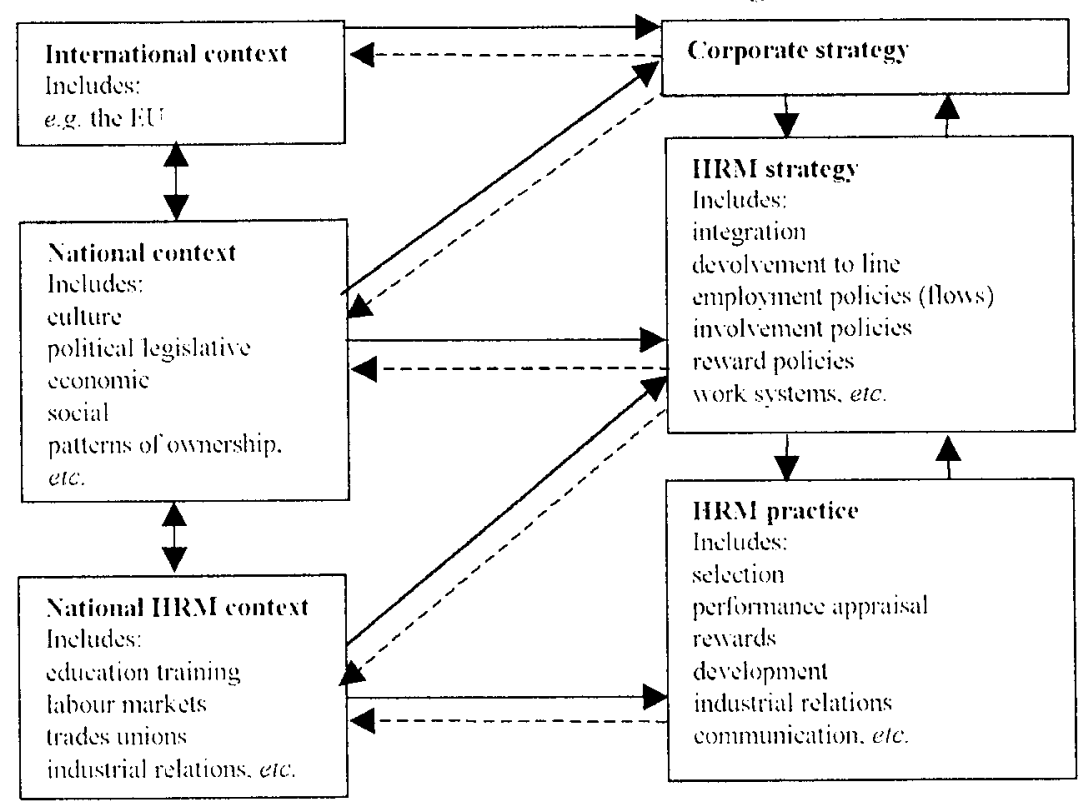

Figure 7: European (Contcxtual) Model of HRM

source: Brewster. C'. (1995). "Towards a 'furopean' model of human resourse managemem" in .Journal of International Business studies, $26(1), 1-21$, p. 14. 


\subsection{The Clark and Mallory Model}

Clark and Mallory have substantial criticisms about Brewster's model. These criticisms are presented under four headings ${ }^{33}$ :

a) Cultural diversity: Drawing on the works of cultural relativist writers, Clark and Mallory question the 'universal appropriateness of management models and theories developed in one country' and suggest that 'the relevance and validity of a theory is limited by national boundaries'. From among these writers they prefer Hofstede in particular.

b) American versus European managerial autonomy: Here, the criticism of Clark and Mallory is on the point that Brewster may have overestimated "the level of autonomy 'enjoyed' by American managers and organisations with respect to human resources matters ${ }^{34 "}$. They argue that in some areas like equal opportunities legislation American organisations are more restricted than their European counterparts.

c) An American or European model?: That Brewster "takes as his central notion of HRM the idea that human resources strategies must integrate with, or be linked to, corporate strategies and that human resources practices must be integrated with and support the human resources strategy $35 "$ is questioned by Clark and Mallory. They assert that this is one of the themes which have dominated the American HRM literature, and that Brewster transferred this conception from the American literature to a different cultural context.

d) Ethnocentrism: Clark and Mallory draw attention to the danger that in determining "whether organisations in a particular nation, or set of nations, adopt a common model of HRM, everything is compared in terms of a common reference point (the original model) and is therefore viewed through a particular lens which tends to filter out the diversity of understandings which may exist in different nations"36.

Under the light of their above criticisms, Clark and Mallory propose an alternative model one of the most typical features of which is that it does not specify any HRM concepts and practices, and instead amplifies cultural and institutional elements: 


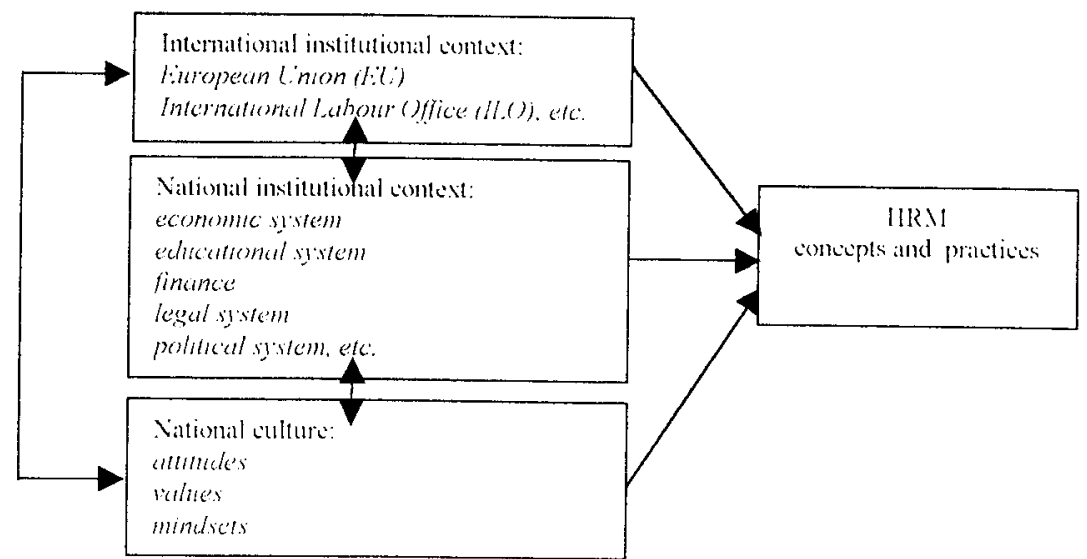

Figure 8: A Framework for the Understanding of National Notions of HRM Source: Clark. I'. and Mallory. (i. (1996) "The cultural relativity of human reseurcis management: Is

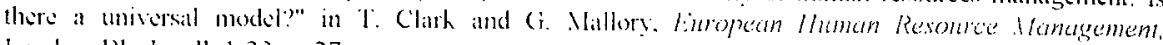
I.ondon: 13lick well. 1-3.3. p.27.

The Clark and Mallory model as such, as its architects state, is based on comparisons in cultural and institutional settings; "(t)o assert that HRM differs in country $\mathrm{A}$ in this or that respect from country $\mathrm{B}$ is incomplete without examining how the cultural and/or institutional framework accounts for the differences found"37. At first sight, their model may be seen akin to Pieper's perception explained above; he too draws attention to cultural or general environmental differences. However, it should be stressed that Pieper is of the idea that HRM is rather a theoretical concept, and what is practised in reality is usually personnel management. He also thinks that the role of culture is exaggerated.

\section{American and European Models Compared}

Despite the differences among them, European models have some common characteristics in contrast to the American ones. Sparrow and Hiltrop summarise them with reference to Brewster and Hegewisch, Hofstede, Guest, and Pieper: 
Table 3: In Relation to American Concepts of HRM, Continental European Concepts Suggest...

1. More restricted employer attonomy:

- himes and liring decisions.

- lower geographic and prolessional employec mobility.

- stronger lint between type of education and aaleer progression.

2. I ess stress on mathet processes:

- human social litie not viswed totally as an comomic tratusation.

- Loner enphasis on the contractual sale of labout by an employse.

3. l心s emplanis on the individual. nore smplakis on the group:

- strong sociological rathar than psichological traditions.

- Less importance on interactions betwcen individuats.

- lomer importanca given to controlling individuals through compctition.

4. Aore cmphasis on workers rather that

managers:

Source: Sparrow and I hiltrop. 1994. p.30.

When we apply the six criteria above to the setting of HRM in Turkey we get the following results in Table 4:
- raison diste for managers derived firom

- Less emphasis on decisive mamagerial heroes.

5. Increalsed role ol "social partners' in tho employment relationship:

- role of trade unions intlustace in the sotling of IIR I policy.

- collective bargaining at the statc and regional level.

- dired co-detemination at the compans? lads.

6. Iligher level ol gorermment intervention or support in many areas of lIR.M: and university systems.

- fombal certification sistems influcmeng persomel selection and calcers.

- comprehensive welfare policiss. people.

- stale role in educition through public school

\section{Which Model is More Suitable for the Turkish Case?}


Table 4: American and Continental European Concepts of HRM Applicd to the HRM Setting in Turker ${ }^{38}$

\begin{tabular}{|c|c|c|c|c|c|c|}
\hline & Restrictions on Fmployer : tutonomy & $\begin{array}{l}\text { Stress on Market } \\
\text { Proccsses }\end{array}$ & $\begin{array}{l}\text { Emplasis on the } \\
\text { Individual }\end{array}$ & $\begin{array}{l}\text { Fimpliasis on Workers } \\
\text { rather than Managers }\end{array}$ & Role of Social Partners & $\begin{array}{l}\text { Level of Government } \\
\text { Intervention or Support }\end{array}$ \\
\hline 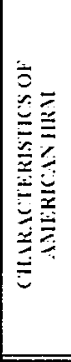 & 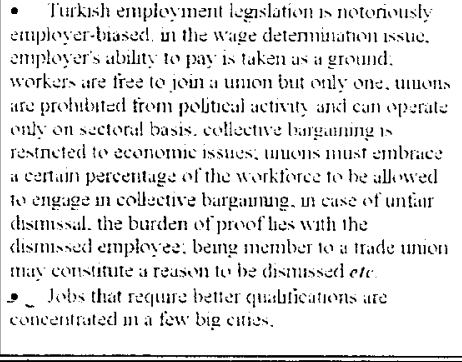 & \multirow{2}{*}{ 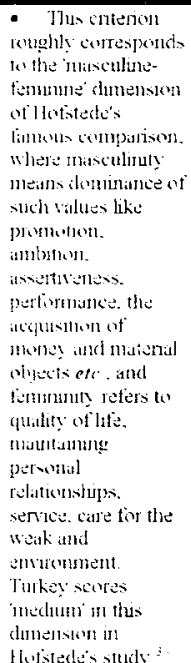 } & - & 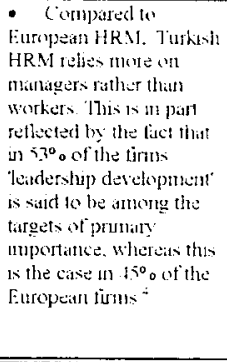 & 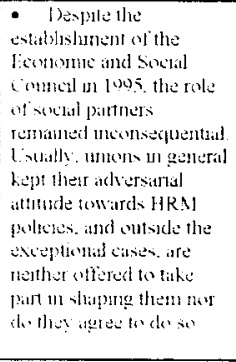 & 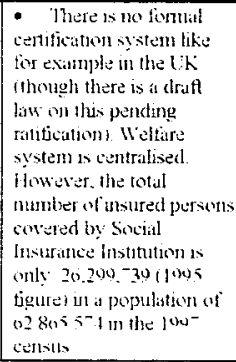 \\
\hline 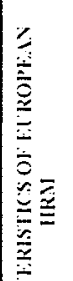 & 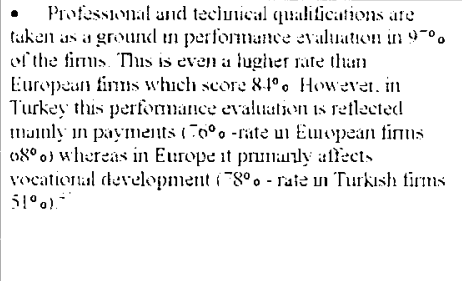 & & 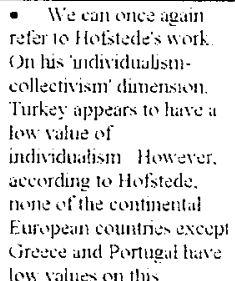 & - & - & 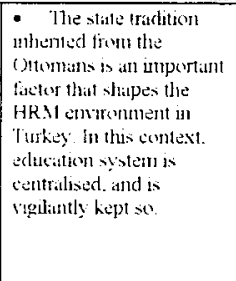 \\
\hline
\end{tabular}


The concept of strategy which Sparrow and Hiltrop did not include among their six criteria is an important component in the matching models of the American HRM. In Turkish HRM, $89 \%$ of the firms declare that they do have an HR strategy. But, the influence of the HRM on shaping the corporate strategy is not significant: only $28 \%$ of the HR directors are a member of managerial board, and $35 \%$ of the firms do not even have an HR manager. ${ }^{42}$

Taking these differences between the HRM practices in Turkey on the one hand and American and European practices on the other, it becomes clear that none of the models exhibited above seems perfectly tailored for the Turkish case; each necessitates some modifications. And since each model above puts emphasis on different points, serves different aims, and uses different variables, each needs a different modification (for instance, the New York model makes inferences from Porter's generic strategies whereas Poole examines the industrial democracy). For our aims here, making some minor alterations on the Brewster-Hegewisch model in Figure 6 above looks preferable since in this way we can embed the important peculiarities of the Turkish case more easily.

The first substantial alteration should be on the relative freedom of the corporate strategy from the law, state and stakeholders including the unions. And secondly, the one-way nature of the relationship between corporate and HR strategies should be manifested in the model. The model, then, takes the following form:

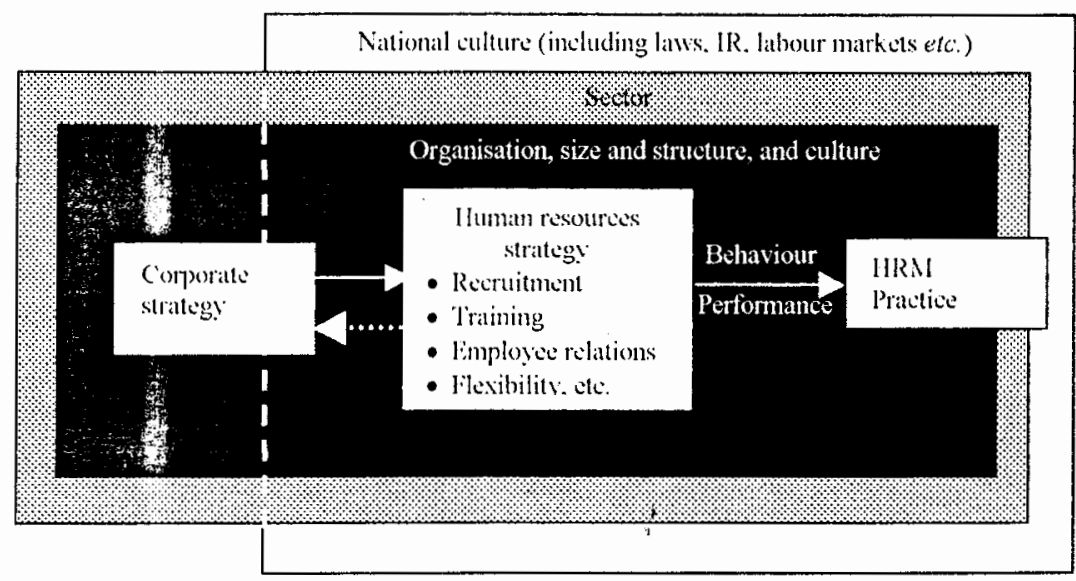

Figure 9: The Brewster and Hegewisch Model Modificd for the HRM Sctting in Turkey 


\section{Conclusion}

American and European models of HRM seem to constitute two different but intersecting spheres. The main sources of difference centre around such criteria like managerial autonomy, consideration of social life as a business-related item, comparative importance attributed to managers and workers, the role of social partners in shaping the HRM area, and the level of government intervention or support. On the basis of some of these criteria, the HRM setting in Turkey seems akin to the one depicted by American models, whereas in some others, it is rather similar to the setting in the European models. It is the claim of this article that Turkish HRM requires a model of its own that calls attention especially to the relative autonomy of Turkish managers, and the partially weak effect of the HR strategy on corporate strategy. This can be achieved by either modifying an existing model, or devising a new one. This article prefers the former, and performs some minor alterations on a European model devised by Brewster and Hegewisch. Nevertheless, this, of course, is a rudimentary attempt, and the challenge of putting forward a better model tailored for the Turkish HRM remains.

\section{Endnotes}

1 R. Pieper (ed.) (1990), Human Resources Management: An International Comparison, New York: Walter de Gruyter.

2 Such as Sisson, K. and Timperley, S. (1994), Personnel Management, London: Blackwell, p.161-167.

3 For example Beardwell, I and Holden, L. (1994), "An introduction to human resource management" in I Beardwell and L. Holden (ed.s) Human Resource Management, London: Pitman Publishing, 14-22.

4 Sparrow, P. and Hiltrop, J-M. (1994), European Human Resources Management, Cambridge: Prentice Hall, pp.6-14.

5 Tichy, N. M., Fombrun, C. J. and Devanna, M. A. (1982), "Strategic human resource management" in Sloan Management Review, 23(2), 47-61 and Fombrun, C. J. Tichy, N. M. and Devanna, M. A. (1984), Strategic Human Resource Management, New York: John Wiley. 
6 Fombrun, C. J. Tichy, N. M. and Devanna, M. A. (1984), Strategic Human Resource Management, New York: John Wiley, p. 7.

7 Schuler R. and Jackson, S. (1987), "Linking comparative strategies with human resource management practices" in Academy of Management Executive, Vol.1, No.3, 207-219.

8 Porter, M. E. (1985), Comparative Advantage, New York: Free Press.

9 Beer, M. Spector, B. Lawrence, P. R. Quinn Mills, D. Walton, R. E. (1984), Managing Human Assets, New York: Free Press.

10 See for example Guest, D. (1987), "Human resource management and industrial relations" in Journal of Management Studies; Guest D. (1989), "Personnel and human resource management: Can you tell the difference" in Personnel Management, January; Guest D. (1989), "Human resource management: its implications for industrial relations and trade unions" in J. Storey (ed.) New Perspectives on Human Resource Management, London Routledge, 41-55; Guest, D. (1990), "Human resource management and the American dream" in Journal of Management Studies, 27(4), 377-397; Hendry, C. and Pettigrew, A. (1986), "The practice of strategic human resource management", Personnel Review, 15(5), 3-8; and Hendry, C. and Pettigrew, A. (1990), "Human resource management: an agenda for the 1990s" in International Journal of Human Resource Management, 1(1), 17 43.

11 Claydon, T. (1994), "Human resource management in the USA" in I Beardwell, and L. Holden (ed.s) Human Resource Management, London: Pitman Publishing, 655-668, p.656.

12 Beer M., Spector, B., Lawrence, P. R. Quinn Mill, D. and Walton, R. E. (1985), Human Resource Management: A General Manager's Perspective ; and Fombrun et al., (1984).

13 Kochan, T. A., Katz, H. C. and McKersie, R. B. (1986), The Transformation of American Industrial Relations, Industrial Relations, New York: Basic Books, p.95.

14 Beer et.al. (1985), p.22.

15 Walton, R. E. (1985), "From control to commitment in the workplace" in Harvard Business Review, March-April, 77-84.

16 Beer et al., (1985); Foulkes, F. K. (1980), Personnel Policies in Nonunion Companies, Englewood Cliffs, NJ: Prentice-Hall. 
17 For a rather idiosyncratic list of factors which may have an effect on the human resources management in Europe, see Büyükuslu, A. R. (1998), Globalizasyon Boyutunda Insan Kaynaklart Yönetimi, İstanbul: Der Yayınlan, pp.118-119.

18 Bean, R. (1994), Comparative Industrial Relations: An Introduction to CrossNational Perspectives, London: Routledge, p.71.

19 Bournois, F. and Brewster, C. (1993), "The need for international comparisons" in European Participation Monitor: Developments in European Human Resource Management, Issue No.7, 19-27, p.19.

20 Holden, L. (1994), "International human resource management" in I Beardwell and L. Holden (ed.s) Human Resource Management, London: Pitman Publishing, 599-624, p.609.

21 Bournois, F. and Chauchat, J.-H. (1990), "Managing managers in Europe" in European Management Journal, 8(1), 3-18, p.5.

22 Pieper, R. (ed.) (1990), Human Resource Management: An International Comparison, New York: Walter de Gruyter, p.18.

23 Shenton, G. (1992), "Towards a definition of European management" in European Foundation for Management Development Forum, 92(2), 10-12.

24 Beer et al. (1984), p.35.

25 Poole, M. (1986), Industrial Relations: Origins and Patterns of International Diversity, London: Routledge and Kegan.

26 Poole, M. (1990), "Editorial: Human resource management in an international perspective" in International Journal of Human Resource Management, 1(1), June, $1-15$, p.3.

27 Ibid., p. 5.

28 Brewster, C. and Bournois, F. (1991), "Human resource management: A European perspective" in Personnel Review, 20(6), 4-13, p.4.

29 See Guest, (1990).

30 Thurley, K. and Wirdenius, H.,(1991), "Will management become 'European'? Strategic choices for organisations" in European Management Journal , 9(2), I 127-34, p.128. 
31 Brewster, C. and Hegewisch, A. (1994), "HRM in Europe: Issues and opportunities" in C. Brewster and A. Hegewisch (ed.s) Policy and Practice in European Human Resource Management: The Price Waterhouse Cranfield Survey, London: Routledge, p. 6.

32 Ibid, p.5-6.

33 Clark, T. and Mallory, G. (1996), "The cultural relativity of human resources management: Is there a universal model?" in T. Clark and G. Mallory, European Human Resource Management, London: Blackwell, 1-33,

34 Ibid., p.20.

35 Ibid., p.21.

36 Ibid., p.22.

37 Clark and Mallory, (1996), p.28.

38 For a more comprehensive exhibit of the factors shaping the HRM in Turkey, see Çakır, A. E. (1999), Human Resources Management In International Context: With Special Reference to the UK, Spain and Turkey, Istanbul: Marmara University: European Community Institute, unpublished $\mathrm{PhD}$ thesis.

39 Hofstede, G. (1980), Culture's Consequences: International Differences in Work Related Values, Beverly Hills: Sage, and Hofstede, G. (1991), Cultures and Organisation: Software of the Mind, London: McGraw-Hill.

40 PriceWaterhouseCoopers (2000), Insan Kaynaklarl Klyaslaması: 2000 Türkiye Raporu, İstanbul: PriceWaterhouseCoopers, İstanbul: Hürriyet Yayınlan, p. 12.

41 Ibid., 25-26.

42 Ibid., 18. 